\title{
DETERMINANTS OF LIFE INSURANCE DEMAND: EVIDENCES FROM INDIA
}

\author{
Ganesh Dash \\ IM, JK Lakshmipat University, Jaipur, India \\ Corresponding Email: ganeshdash@hotmail.com
}

\begin{abstract}
Post- IRDA Indian life insurance sector has become highly competitive and innovative. Every life insurer is trying to find out those demographic and socio-economic characteristics of the potential customers responsible for influencing their decisions to buy a life insurance policy. This study has discussed numerous variables associated with the customers such as: age, gender, marital status, occupation, education, family size and annual income and their impact on their buying behaviours. It also included residing locality, selling company and annual premium amount (price) along with these variables. The study was conducted in rural Odisha with a sample of more than 400 life insurance policy holders. To find out significant variations and relationships among these different categories, one-way ANOVA test and correlation analysis was applied. Further, factor analysis (EFA and CFA) and linear multiple regression were used to find out significance. This study is going to help the life insurers understand the various factors involved in influencing the prospective customers to choose a policy.
\end{abstract}

Keywords: Demand, Demographic, Socio-Economic, Determinant, Indian, Life Insurance

\section{Introduction}

The marketers in life insurance business always have a question in their mind. Various demographic and socio-economic relative indicators are responsible for the final purchase decision. Numerous theoretical frameworks and models were developed to analyse the demand for life insurance in the second half of $20^{\text {th }}$ century. These earlier models developed by the authors who believed life insurance as a solution to minimise the uncertainties in the income patterns of a family when the head of the family dies. This school of thought had Yaari (1965); Fischer (1973); Pissarides (1980); Lewis (1989); Bernheim (1991) as the proponents. But, Lewis had a major difference from others by mentioning his objective of the study as meeting the survivors' needs, i.e. maximising the beneficiaries' lifetime utility (expected) whereas the others had believed in maximisation of the policy holder's expected lifetime utility. After formulating a model to explain the factors responsible for rise in consumption of life insurance, he found that life insurance consumption increases with increase in the probability of the death of insured. Further, if the insured survives the stipulated term, then the current consumption value of all the survivors is positively correlated with the life insurance consumption. Again, policy price and wealth of the household affect the life insurance consumption adversely, whereas the household's willingness to avoid risk creates more demand for life insurance cover. Basically, the old 
school $^{1}$ had always considered premium payments as the measure of life insurance consumption due to the easy availability of data and helpful in comparative analysis with previous studies. But, the aggregate value of the policies is a better tool to assess the consumption level; because it calculates the protection level if the insured dies within the term of policy.

Various marketers have put forward their theories and models regarding to the determinants of life insurance demand. This study tries to assess the same and to validate or to negate the propositions. The same has been done with the help of an empirical data which can be generalised with a very few assumptions. Ultimately, every marketer wants to enhance the end product based on the specific determinants of the demand.

\section{Review of Existing Studies}

Hammond et al (1967) established through household survey that life insurance consumption is hugely influenced by family life cycle, income, net worth, education standard and respective occupations of the customers. Similarly, according to Mantis \& Farmer (1968), demand for life insurance is dependent on income, birth rate, population, policy pricing and employment. Hammond et al (1967) and Lewis (1989) outlined the major cause of buying a life insurance policy was to help the survivors with economic gains if the insured dies before the end of the term stipulated. The number of dependents of the policy holder positively influences the consumption of life insurance (Beenstock et al, 1986). But, few studies, namely, Ferber \& Lee (1980) and Goldsmith (1983) have found this relationship as negative. Numerous studies have proved that income of the insured positively affects the demand for life insurance. Hakansson (1969) and Campbell (1980) along with Lewis have derived a positive correlation between income and life insurance purchasing decision. Duker (1969) made a case for family with working wife. He found that working -wife families buy less life insurance products than the families with house wives. He stressed on the need to focus on the working- wife families. Age, family size and birth rate significantly influence the customers to buy life insurance cover (Berekson, 1972). Cummins (1973) analysed the impact of various macroeconomic factors on the life insurance sector of the USA. This study outlined the various factors responsible for causing fluctuations in the demand for life insurance products. The results of the study made a great contribution in understanding the demand for a life insurance product better.

It was found that life insurance along with pension reserves (insured) are positively correlated with Gross National Product and income (permanent). According to Fortune (1973), income, net worth and the customer's confidence influence the consumption of life insurance. Customer emotions, savings and policy price play a major role in determining the consumption level of life insurance (Headen \& Lee, 1974). Normally, inflation has a negative impact on the demand for life insurance due to loss of value of the investment (to some extent) (Fortune, 1974). The amount of inflation expected by the customers is totally dependent on the rate of inflation in the previous years (Choate \& Archer, 1975). While considering the time lag involved in purchase time and realisation time, inflation is a very important factor influencing the customers to rethink about the purchasing decision. Therefore, inflation plays a major role in creating demand for life insurance (Babbel, 1981). Greene (1954) also found that insurance lacks protection against inflation. Similarly, Neumann (1969) outlined that there is almost zero relationship between the expected prices and life insurance consumption. But some studies have found a relationship between inflation and demand for life insurance. These studies included Hofflaner \& Duvall (1967) 
and Fortune (1972). Fortune has found a positive relationship between inflation and the demand for life insurance. Anderson \& Nevin (1975) made a survey of young married couples and outlined that current income, expected income; husband's education, net worth and the wife's income (pre-marriage) are the factors which decide the level of demand for life insurance. Various traits of the customer affect his/ her decision to buy life insurance. Psychological traits such as fatalism, socialising, religious beliefs, old work ethics and assertiveness are responsible in fixing the demand level foe life insurance. Similarly, demographic traits such as education, income and family size influence the customer to buy a life insurance product. People moving frequently between places possess less number of life insurance (Burnett \& Palmer, 1984). Zeilzer (1979) believed that religion has created a negative perception about life insurance since long time. Religious people, especially, Catholics, Muslims and a few other sects oppose life insurance coverage, proposing that it is an insult to the God's power of protection. Religion and culture can affect a person's perception on risk aversion which results in less demand for life insurance (Douglas \& Wildavsky, 1982). Miller (1985) has found that working people have more number of policies than retired people (same age) because of the employer's cost-cutting operation and absence of government's recognition of life insurance coverage for retired employee. Higher interest rates (more influential) and increased life expectancy (less influential) basically negatively affect the life insurance demand (Williams, 1986).

Fitzerald (1987) categorised positive and negative determinants of life insurance consumption. Positive determinants were husband's future income (expected) and wife's income (expected). Similarly, a negative determinant was the benefits expected at the husband's survival of the stipulated term. Age, education and income positively influence the demand for life insurance (Truett\& Truett, 1990). Wealth has a huge positive influence on the purchase of life insurance (Benheim, 1991).

It depends on a variety of factors to get in to a customer's investment portfolio. Dependency ratio, religion, income, social security, expected inflation rate, average life expectancy, education and policy loading charges are the few factors which affect the demand for a life insurance product (Browne \& Kim, 1993). They put the relationship (both positive and negative) of the factors in the following equation:

$$
\begin{aligned}
& \log (\mathrm{Yi})=\beta_{o}+\beta_{1} \log (\mathrm{DEPi})+\beta_{2} \mathrm{MUSi}+\beta_{3} \log (\mathrm{INCi})+\beta_{4} \log (\mathrm{SSEi})+\beta_{5} \log (\mathrm{INFi})+\beta_{6} \log \\
& (\mathrm{EDUCi})+\beta_{7} \log (\mathrm{LEi})+\beta_{8} \log (\mathrm{Pi})+e i
\end{aligned}
$$

where, $\mathrm{Yi}=$ life insurance per capita in country $\mathrm{i}, \mathrm{DEPi}=$ dependency ratio in country $\mathrm{i}$ (positive), $\mathrm{INCi}=$ income per capita in country I (positive) as a replacement for disposable personal income for which the data is never available, $\mathrm{SSEi}=$ social security expenditures per capita in country i (uncertain), INFi = expected inflation rate in country i (calculated average of last eight years' inflation rate) (negative), $\mathrm{Pi}=$ insurance loading charge in country i , i.e. the policy price (negative), EDUCi = rate of third-level education in country i (positive), LEi = Life expectancy in country $\mathrm{i}$ (the probability of death) (negative), MUSi = Classification variable which takes the value of 1 if country i's population is predominantly Islamic and 0 otherwise (negative), and ei $=$ the random error term.

Age, income, number of family member with income and family size have a positive relationship between themselves where as there is a negative relationship between age and demand for insurance, family size and insurance demand as well as income and number of earners (Showers \& Shotick, 1994). Hau (2000) noted that wealth and net worth influence the customers positively to buy life insurance whereas demographic variables have less 
impact on the customer's decision to buy a policy. Zietz (2003) went through an extensive collection and review of literature to find the determinants of life insurance demand. He reviewed almost every literature available that deal with life insurance demand in last fifty years. Various demographic and economic factors responsible for affecting the demand for life insurance as well as the environmental factors were discussed. Though there were numerous studies conducted to find out the determinants of demand for life insurance, many of them had conflicting results. The relationship between various factors life insurance demand varied from study to study. In this study, an attempt was made to ascertain the factors responsible for increase in demand for life insurance.

The proposed hypothesis based on global trends is given below:

Life Insurance Demand $=f$ \{ncome (+ve), Financial Development (+ve), Rate of Interest (of alternate products) (-ve), Inflation (-ve), Education (+ve), Life Expectancy (+ve), Urbanisation (+ve)\}, which can also be expressed as:

L $=f$ [I+ F.D. - R.I. - INF. + L.E. + EDU. +URB. $]$

To test the hypothesis, the authors have taken data from the annual data series for the postIRDA period, i.e. from 1999 to 2008. After a thorough empirical analysis, they found that among economic variables, income and financial development are the most positive and important determinants of life insurance consumption in India. But, inflation was also found to be important and positively correlated to demand negating the worldwide trend whereas interest rate negatively influences the customers to buy life insurance. Among non-economic factors, education was found to be the most important and positively correlated to life insurance demand in India.

\section{Objectives}

The sole objective of this study was to find out the various demographic and socio-economic factors (of the life insurance consumers) responsible for influencing their policy purchasing decision. For this purpose, the various factors discussed in this study are outlined as: age, gender, education, marital status, family size, income, occupation, choice of selling company (public or private), annual premiums (price) and residing locality. The dependent factor was established as the number of policy purchased by the customers (keeping the minimum policy premium at Rupees Five Thousands per annum). Hence, the research question was outlined as: Which demographic and socio-economic characteristics (of the customers) influence the customers most in buying a life insurance policy?

\section{Research Design}

\section{Research Methodology}

For this study, the descriptive approach was adopted rather than experimental research method because the theme of this study was on analysing the perception of the customers regarding the given demographic and socio-economic variables with respect to their policy buying behaviour which can be better assessed through descriptive research methods. Organisation wise, $\mathrm{LIC}^{2}$ (1 public life insurer) and 4 private life insurers were included in this study (not the sample size, see sample design). It also investigates the socio-economic status and the life insurance policy buying behaviour of the targeted population in the study area.

\section{Data Collection}

This study was conducted in south Odisha (Eastern India) which is pre-dominantly rural in nature. The data collection zone was limited to two districts of this region, namely, Ganjam and Gajapati. It consists of two towns with more than one hundred thousand populations 
and rest of the area is semi-urban and rural. The data collection method was basically primary on the basis of a sampling design consisting both convenient and quota sampling strategies. The data collection period was between July and August of 2017. The required information was obtained through a structured questionnaire (with personal presence) containing all the above discussed variables derived from the review of literature.

\section{Sample Design and Selection}

The study area in question has three major branches of LIC and 11 major branches of the private life insurers. The population is defined as follows: "customer" means people who have bought a policy in the last quarter (3 months) and "executive" means people who have sold a policy in the last quarter (3 months). It was found that more than 30,000 people have bought life insurance policiees in the last quarter whereas more than 900 executives have sold at least one policy. An item-respondent ratio of 1:6 was recommended by Hinkin (1995) and Heir et al (2006) suggest a higher ratio of 1:5. Though, the ratio of 1:10 is a standard accepted worldwide, an item:respondent ratio of more than 1:10 was adopted for this study. Due to time constraint, the sample size for the customers was limited to 405. Out of the 14 branches, 6 branches were included in this study (LIC (2) and private (4)). Out of 405 customers, 201 belonged to LIC and 204 belonged to the private insurers take together.

\section{Results and Discussions}

The data collected were coded and datasheets for customers are prepared for analysis using SPSS 18. For modelling, AMOS 18 was used. After getting the required data, various statistical tools such as percentage, cross tabulation, mean and variance were applied to find any variation among the different classes of customers (based on their demographic/ socioeconomic characteristics) with regard to their policy buying behaviour (the amount of policies purchased by them). Further, to find out significant variation among these different types of customers, one-way ANOVA was applied. Correlation analysis was also carried out to analyse the relationship between a few demographic characteristics (with similar categorisation- incremental) of the customers. Further, EFA \& CFA were conducted to test the multicollinearity found in correlation. With the help of AMOS, CFA was prepared along with linear multiple regression.

\section{ANOVA (one- way) Results}

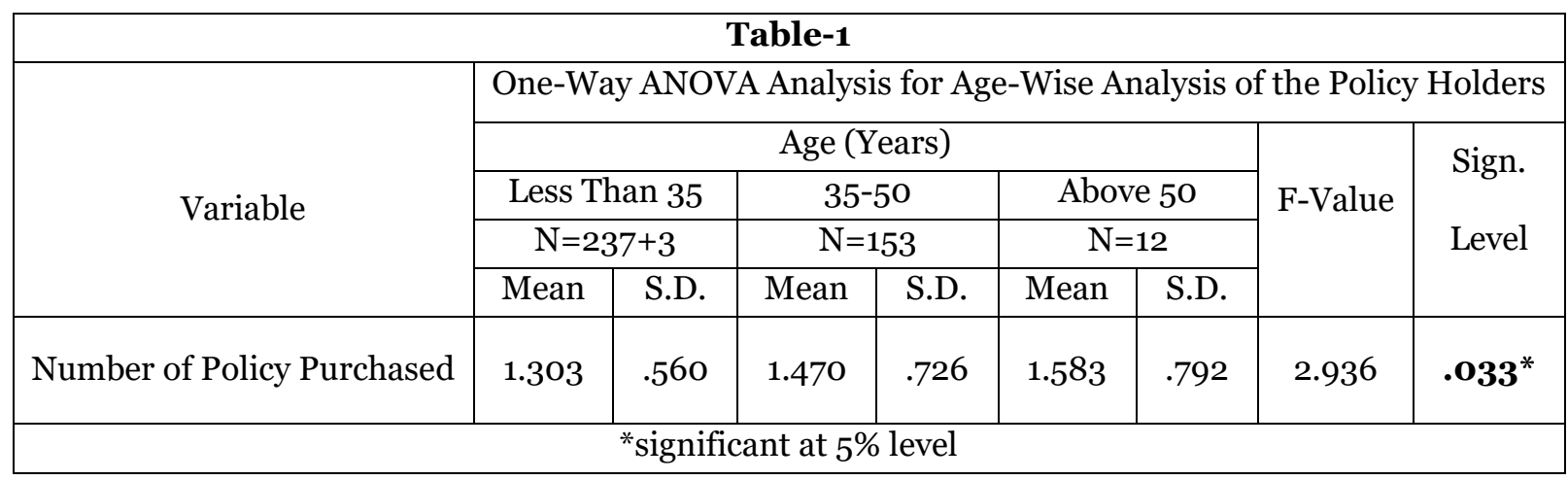

Age: as it can be seen from the table -1, the number of policy purchased goes up with the age. People try to buy more number of policies with the advanced age. Further, the resultant F- value (ANOVA) proved that age has a significant impact on the customers' life insurance policy buying decision. 
Gender: both male and female customers possess almost same number of policies (though the female customers are slightly ahead). The following $\mathrm{F}$ - value proved this notion (see table-2).

\begin{tabular}{|c|c|c|c|c|c|c|}
\hline \multicolumn{7}{|c|}{ Table-2 } \\
\hline \multirow{5}{*}{ Variable } & \multicolumn{6}{|c|}{$\begin{array}{l}\text { One-Way ANOVA Analysis for Gender-Wise Analysis of the Policy } \\
\text { Holders }\end{array}$} \\
\hline & \multicolumn{4}{|c|}{ Gender } & \multirow{4}{*}{ F-Value } & \multirow{4}{*}{ Sign. Level } \\
\hline & \multirow{2}{*}{\multicolumn{2}{|c|}{$\begin{array}{c}\text { Male } \\
\mathrm{N}=265\end{array}$}} & \multirow{2}{*}{\multicolumn{2}{|c|}{$\begin{array}{l}\text { Female } \\
\mathrm{N}=140\end{array}$}} & & \\
\hline & & & & & & \\
\hline & Mean & S.D. & Mean & S.D. & & \\
\hline $\begin{array}{l}\text { Number of Policy } \\
\text { Purchased }\end{array}$ & 1.358 & .648 & 1.4 & .620 & .387 & .534 \\
\hline & & gnifica & $5 \%$ ley & & & \\
\hline
\end{tabular}

Marital status: Further discussing about the impact of marriage on the policy purchasing decision, it was found that marriage has almost no impact on this aspect, although married people seemed to have slightly more number of policies than unmarried people. The corresponding F- value justified the finding (see table-3).

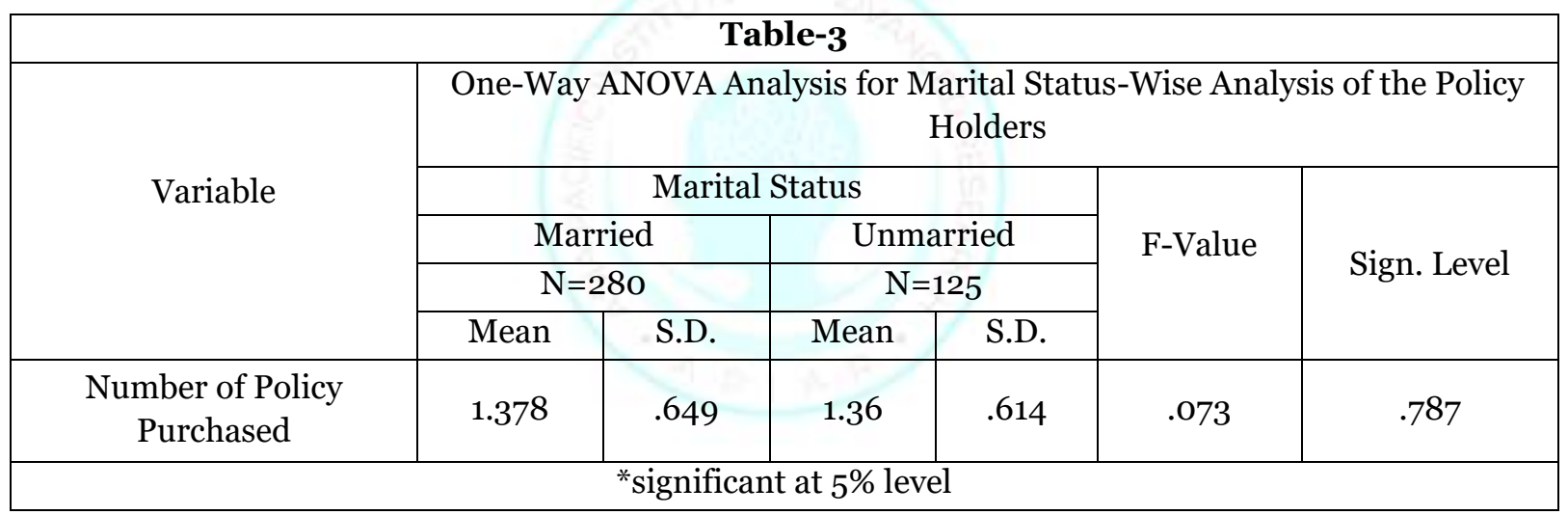

Selling company: as it can be seen from the table-4, it was found that selling company has almost no impact on the customers' buying decision although customers of private insurers seemed to possess more number of policies than those of LIC. This result was strengthened by the following ANOVA test.

\begin{tabular}{|c|c|c|c|c|c|c|}
\hline \multicolumn{7}{|c|}{ Table-4 } \\
\hline \multirow{5}{*}{ Variable } & \multicolumn{6}{|c|}{$\begin{array}{l}\text { One-Way ANOVA Analysis for Company-Wise Analysis of the Policy } \\
\text { Holders }\end{array}$} \\
\hline & \multicolumn{4}{|c|}{ Company } & \multirow{4}{*}{ F-Value } & \multirow{4}{*}{ Sign. Level } \\
\hline & & & \multirow{2}{*}{\multicolumn{2}{|c|}{$\begin{array}{l}\text { Private } \\
\mathrm{N}=204\end{array}$}} & & \\
\hline & \multicolumn{2}{|c|}{$\mathrm{N}=201$} & & & & \\
\hline & Mean & S.D. & Mean & S.D. & & \\
\hline $\begin{array}{l}\text { Number of Policy } \\
\text { Purchased }\end{array}$ & 1.348 & .669 & 1.397 & .607 & .591 & .443 \\
\hline
\end{tabular}


Locality: Again, discussing about the impact of residing locality (urban or rural) on the policy purchasing decision of the customers, it was found that it has almost no impact on this aspect although urban customers seemed to have bought more number of policies than rural customers. The following F-value proved this notion (see table-5).

\begin{tabular}{|c|c|c|c|c|c|c|}
\hline \multicolumn{7}{|c|}{ Table-5 } \\
\hline \multirow{5}{*}{ Variable } & \multicolumn{6}{|c|}{$\begin{array}{l}\text { One-Way ANOVA Analysis for Locality-Wise Analysis of the Policy } \\
\text { Holders }\end{array}$} \\
\hline & \multicolumn{4}{|c|}{ Locality } & \multirow{4}{*}{ F-Value } & \multirow{4}{*}{ Sign. Level } \\
\hline & \multirow{2}{*}{\multicolumn{2}{|c|}{$\begin{array}{l}\text { Urban } \\
\mathrm{N}=163 \\
\end{array}$}} & \multirow{2}{*}{\multicolumn{2}{|c|}{$\begin{array}{c}\text { Rural } \\
\mathrm{N}=242\end{array}$}} & & \\
\hline & & & & & & \\
\hline & Mean & S.D. & Mean & S.D. & & \\
\hline $\begin{array}{l}\text { Number of Policy } \\
\text { Purchased }\end{array}$ & 1.411 & .682 & 1.34 & .607 & .977 & .324 \\
\hline
\end{tabular}

Occupation: As seen in table- 6, that occupation has a significant impact on the customers' buying decision. Government employees have much more number of policies followed by the self-employed/ business category customers whereas private employees and the others have fewer policies. To test these variations, one- way ANOVA test was carried out and it was found that the difference was highly significant.

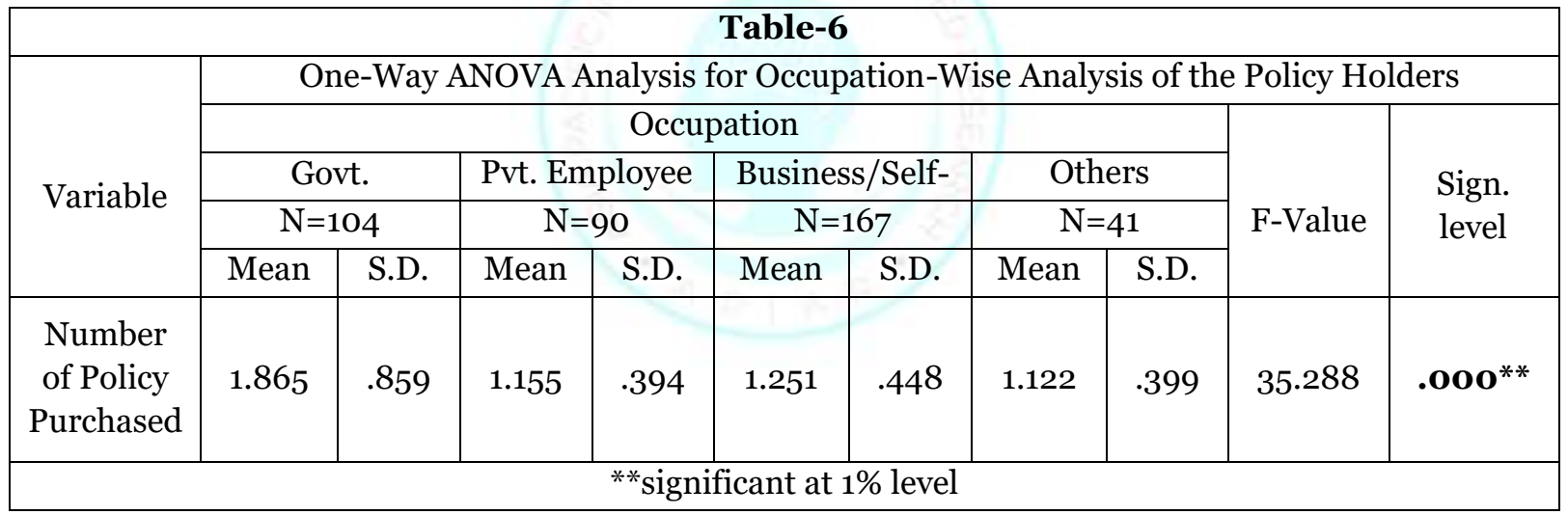

\section{EFA \& CFA}

From the correlation table, it was found that educational qualifications, yearly premiums paid and annual income are having a strong correlation among themselves. This is a case for multi-collinearity. Hence, these variables can be put under a single factor. For the same, EFA as well as CFA was conducted (Table-7 \& Figure-1 respectively). First of all, KMO \& Bartlett's Test of sphericity were measured which were found to be satisfactory. The rotated factor matrix has proved the assumption of multi-collinearity between theses variables. These three variables are grouped under Factor F1 whereas family size is another factor. The same was confirmed by the CFA. 
Table-7 EFA

KMO and Bartlett's Test

\begin{tabular}{|cc|c|}
\hline Kaiser-Meyer-Olkin Measure of Sampling Adequacy. & $\mathbf{. 7 0 7}$ \\
Bartlett's Test of Sphericity & Approx. Chi-Square & 419.313 \\
& Df & 6 \\
Sig. & $\mathbf{. o o o}$ \\
\hline
\end{tabular}

\begin{tabular}{|l|r|r|}
\hline \multicolumn{1}{|c|}{ Rotated Component Matrix ${ }^{\mathbf{a}}$} \\
\cline { 2 - 4 } \multicolumn{1}{c|}{} & \multicolumn{3}{|c|}{ Component } \\
\hline EDUQLFN & 1 & \multicolumn{2}{|c|}{2} \\
FAMILYSIZE & .714 & -.153 \\
YRLYPREM & -.023 & .987 \\
ANNINCOME & .868 & .148 \\
\hline
\end{tabular}

Figure-1 CFA

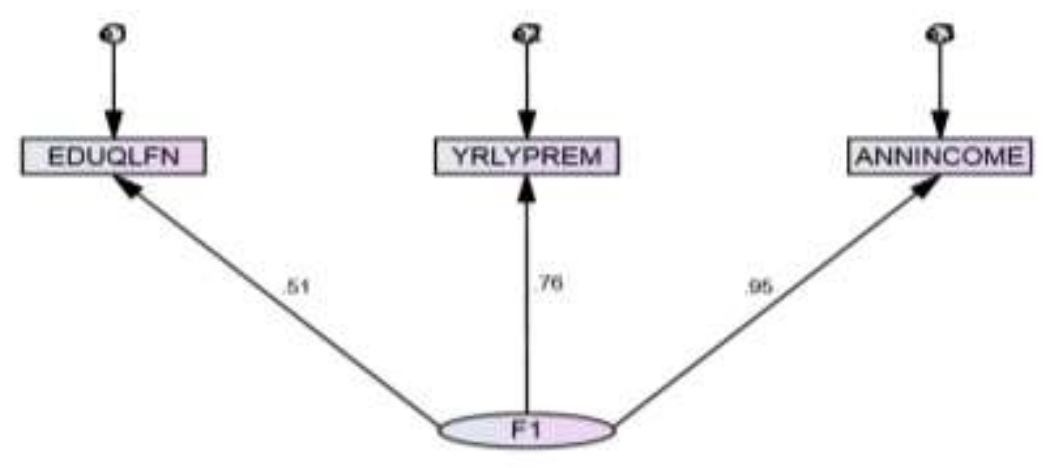

\section{Regression}

Furthermore, we have conducted a linear multiple regression between the number of policies (depndent), F1 (independent) and Family Size (independent) (Table-8 \& Figure-2 respectively). The model was found to be significant as seen form the ANOVA results. Further, $\mathrm{R}^{2}$ was found to be 0.7 which is a good measure. Speaking of individual impact, F1 has a beta value of 0.64 which is significant whereas the impact of family size is not significant and is also negligible. The same is depicted by the model developed in the following figure.

\section{Table-8}

\section{Regression}

\begin{tabular}{|l|c|r|r|r|}
\hline Model & $\mathrm{R}$ & $\begin{array}{c}\mathrm{R} \\
\text { Square }\end{array}$ & $\begin{array}{c}\text { Adjusted } \\
\text { R Square }\end{array}$ & $\begin{array}{c}\text { Std. Error } \\
\text { of the } \\
\text { Estimate }\end{array}$ \\
\hline 1 & $.837^{\mathrm{a}}$ & $\mathbf{. 7 0 0}$ & .696 & .49341 \\
\hline
\end{tabular}




\begin{tabular}{|lr|r|r|r|r|r|}
\hline \multicolumn{2}{|l|}{} & & & & & \\
\hline 1 & Sum of Squares & Df & Mean Square & F & Sig. \\
& Regression & 66.832 & 2 & 33.416 & 137.257 & $.0^{\mathrm{O}}$ \\
& Residual & 97.869 & 402 & .243 & & \\
& Total & 164.701 & 404 & & & \\
\hline
\end{tabular}

a. Dependent Variable: NOPOLICY

b. Predictors: (Constant), F1, FAMILYSIZE

Coefficientsa $^{\mathbf{a}}$

\begin{tabular}{|c|c|c|c|c|c|c|}
\hline \multirow{2}{*}{\multicolumn{2}{|c|}{ Model }} & \multicolumn{2}{|c|}{ Unstandardized Coefficients } & \multirow{2}{*}{$\begin{array}{c}\begin{array}{c}\text { Standardized } \\
\text { Coefficients }\end{array} \\
\text { Beta }\end{array}$} & \multirow[b]{2}{*}{$\mathrm{T}$} & \multirow[b]{2}{*}{ Sig. } \\
\hline & & B & Std. Error & & & \\
\hline \multirow[t]{3}{*}{1} & (Constant) & -.002 & .097 & & -.017 & .987 \\
\hline & FAMILYSIZE & .014 & .015 & .036 & .942 & .347 \\
\hline & F1 & .624 & .038 & 637 & 16.562 & .000 \\
\hline
\end{tabular}

a. Dependent Variable: NOPOLICY

Figure-2

Regression

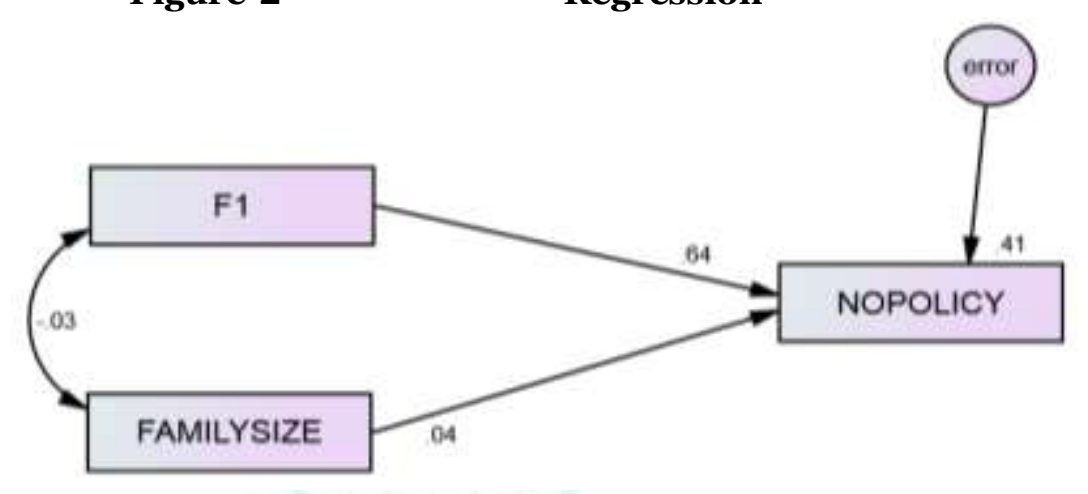

After summarising the findings, the results needed to be discussed in detail. For this purpose, the results of earlier studies (wherever available and/or applicable) were taken in to consideration.Demand for life insurance is positively influenced by age, income and education whereas price/ cost (premiums) negatively affects the demand. Type of occupation also affects the demand for life insurance. But, gender, marital status, selling company, locality and family size have no impact on the demand for life insurance product.

As the review of earlier literatures showed that these results differ from lot of studies' findings, the factors responsible for creating demand for life insurance should be studied in detail.This study has found that age has a positive relationship with life insurance demand which is supported by Berekson (1972) and Truett\& Truett (1990). But, Showers \& Shotick (1994) had found that age has a negative impact on life insurance demand. Browne \& Kim (1993) had found that age is insignificant for the demand of life insurance product. This study has found that income positively influence the demand for life insurance. This finding is generally supported by all the earlier studies reviewed in this study. All the researchers mentioned in this study have found a positive relationship between income and the life insurance demand. Yaari (1965); Hakansson (1969); Fischer (1973); Campbell (1980); Beenstock et al (1986); Browne \& Kim (1993); Outtreville (1996); Enz (2000) and Hwang \& Greenford (2005) are a few authors who support this finding. 
Now coming to level of education of the customers, the life insurance demand is positively affected by this criterion. Beenstock et al (1986); Truett\& Truett (1990); Outtreville (1996); and Beck \& Web (2003) have found the same relationship. But, Browne \& Kim (1993) had found that education is insignificant for life insurance demand.

Price, i.e. the premiums cost of the life insurance negatively influence the demand for life insurance. This study has found that though the amount of premiums goes up with the number of policies, (as sheer numerical relationship) the real demand goes down with more amount of premiums asked by the life insurers. This finding is in line with the outcomes of the studies done byBabble (1981), Beenstock et al (1986); Browne\& Kim (1993) and Lim \& Hiberman (2004). But, two studies namely, Outtreville (1996) and Ward \& Zurbruegg (2002) had found a positive relationship between price and life insurance demand. But, Hwang \& Greenford (2005) say that price has no impact on life insurance demand.

Additionally, the Type of occupation has a positive impact on the life insurance demand. It was found that government servants were buying more life insurance policies than others. Hammond et al (1967); Mantis \& Farmer (1968); Anderson \& Nevin (1975) had and Miller (1985) established a positive relationship between occupation/ employment and life insurance demand.Gender has no influence on the demand for life insurance. There was no mention about gender in any of the earlier studies. Similarly, marital status has no impact on the demand for life insurance. Anderson \& Nevin (1975) had mentioned about the positive impact of marriage on life insurance demand. This study has found that the impact of family size on life insurance demand as insignificant. But, almost the entire old school had mentioned this criterion as the most important factor in creating life insurance demand. Hammond et al (1967); Mantis \& Farmer (1968); Berekson (1972); Beenstock et al (1986) and Lewis (1989) had also supported this view. But, Ferber \& Lee (1980) and Goldsmith (1983) have found this relationship as negative.

This study has found that urbanisation (locality) has no impact on the demand for life insurance. But, almost all studies had found that it has a positive effect on the life insurance demand. Outtreville (1996); Beck \& Web (2003) and Hwang \& Greenford (2005) were among this theory's proponents.

\section{Conclusion}

After discussing about the various determinants of life insurance demand, the final relationship between the life insurance demand and the variables discussed in this study can be outlined as below:

Life Insurance Demand $=f\left\{\right.$ Age ${ }^{*}(+)$, Gender $(N)$, Marriage $(N)$, Company $(N)$, Locality $(N)$, Occupation $^{* *}(+)$, Income $^{* *}(+)$, Family Size $(N)$, Education $^{*}(+)$, Price $\left.^{* *}(-)\right\}$,

[Relationship signs can be read as: $+=$ positive, $-=$ negative, $\mathrm{N}=$ Neutral] (* means significant at $5 \%$ and ${ }^{* *}$ means significant at $1 \%$ )

Based on the findings, a few suggestions can be made. It was found that younger customers possess less number of policies and therefore, life insurers should redesign their products targeting this segment. As the life expectancy of this group is very high, survival/ maturity benefits have to be given a thrust rather than post- death benefits. The policy tenure should be curtailed to make it look like any other investment plans. In rural India, the average life expectancy of a female is more than a male. Specific policies targeted at the female customers, especially single mothers and widows, should be encouraged to cater to this 
population. Attractive plans and packages, particularly health related products should be created to attract a huge market of single (both unmarried and widowers) male customers. The Most important aspect of Indian life insurance sector is it is evenly divided between the LIC and the private insurers as a whole. There is a wide- spread belief is that the private companies are giving a tough fight to the LIC (leading now) in urban area, but leaving the entire rural market to the public sector to monopolise. This scenario must be changed to remove the gap between urban and rural markets as India is pre-dominantly rural.

Furthermore, compared to government employees, private employees and others are buying less number of policies which demonstrates the life insurers are more interested in salaries and guaranteed regular income groups who can pay the premiums regularly. This aspect can be changed with more single-term plans to target the business/ self-employed groups. Similarly, products with flexible premium payment options should be created to attract the private employees. An ideal mix of medium to high net worth individuals with high income levels (with more disposable income) should be targeted. Specific policies to augment their wealth along with adequate risk coverage should be promoted. Similarly, people with lower incomes should be given low premium flexible plans. Prospective customers who are highly educated can be sold the policies by providing a rational and tangible reason to buy a life insurance product. But, for customers with less/ no education, the front line executives have to make an extra effort with the help of incentives and/ or discounts.

Policy pricing is another important factor to affect the prospective customers' psyche to buy a policy. The price level should be well within the affordability level of the customer. Flexibility and convenience of terms of payment must be followed as per the requirements of the potential customer. The life insurance companies must ensure that the price of the policy should not exceed its worth as anticipated by the buyer. Again, a transparent comparison with the price levels of similar policies provided by the rival companies should be made before the prospective buyers. A clear and simple price structure should be provided by the selling companies to the customer that can be understood easily by a lay man. Further, discounts and incentives should be included in the pricing structure in order to attract buyers. Though the present situation is unstable and turbulent due the recessional effect felt world-wide, the overall scenario for the Indian life insurance sector seems very rosy aided by the fact that the life insurance penetration rate remains very low, as well as the huge potential of the rural sector which still remains untapped. 


\section{References}

i. Anderson, D. R. and Nevin, J. R., 1975. Determinants of Young Marrieds' Life Insurance Purchasing Behavior: An Empirical Investigation. Journal of Risk and Insurance, Volume 42, pp. 375- 387 .

ii. Babbel, D. F., 1981. Inflation, Indexation and Life Insurance Sales in Brazil. Journal of Risk and Insurance, Volume 48, pp. 115-135.

iii. Beck T. and Webb I., 2003. Economic, Demographic and Institutional Determinants of Life Insurance Consumption across Countries, Working Paper.s.l.: World Bank And International Insurance Foundation.

iv. Beenstock M., Dickinson G. and Khajuria S.,1988. The Relationship Between Property- Liability Insurance Premiums And Income: An International Analysis. The Journal of Risk and Insurance, 55 (2), pp. 259-272

v. Berekson, L. L., 1972. Birth Order, Anxiety, Affiliation and the Purchase of Life Insurance. Journal of Risk and Insurance, Volume 39, pp. 93-108.

vi. Bernheim, B. Douglas, 1991. How Strong Are Bequest Motives? Evidence Based on Estimates of the Demand for Life Insurance and Annuities. Journal of Political Economy, Volume 99, pp. 899-927.

vii. Browne, Mark J. and Kim, Kihong, 1993. An International Analysis of Life Insurance Demand. The Journal of Risk and Insurance, 60 (4), pp. 616-634.

viii. Burnett, J. J., and Palmer, B. A., 1984. Examining Life Insurance Ownership Through Demographic and Psychographic Characteristics. Journal of Risk and Insurance, Volume 51, pp. 453- 467.

ix. Campbell, R. A., 1980. The Demand for Life Insurance: An Application of the Economics of Uncertainty. Journal of Finance, Volume 35, pp. 1155-1172.

x. Choate, C. M. and Archer, S., 1975. Irving Fisher, Inflation and the Nominal Rate of Interest. Journal of Financial and Quantitative Analysis, Volume 4, pp. 675-685.

xi. Cummins, J. David, 1973. An Econometric Model of the Life Insurance Sector of the U.S. Economy. Journal of Risk and Insurance, Volume 40, pp. 533-554.

xii. Douglas, Mary and Wildavsky, Aaron, 1982.Risk and Culture. Berkeley: University of California Press.

xiii. Duker, J. M., 1969. Expenditures for Life Insurance Among Working-Wife Families. Journal of Risk and Insurance, Volume 36, pp. 525-533.

xiv. Enz R., 2000. The S-Curve Relation Between Per Capita Income and Insurance Penetration. The Geneva Papers On Risk And Insurance: Issues And Practice, 25 (3), pp. 393-406.

xv. Ferber, Robert and Lee, Lucy Chao, 1980. Acquisition and Accumulation of Life Insurance in Early Married Life. Journal of Risk and Insurance, Volume 47, pp. 713-729.

xvi. Fischer, Stanley, 1973. A Life Cycle Model of Life Insurance Purchases, International Economic Review, Volume 14, pp. 132-152.

xvii. Fitzgerald, J., 1987. The Effects of Social Security on Life Insurance Demand by Married Couples. Journal of Risk and Insurance, Volume 54, pp. 86-99.

xviii. Fortune, P., 1972. Inflation and Saving Through Life Insurance: Comment. Journal of Risk and Insurance, Volume 39, pp. 317-326.

xix. Fortune, P., 1973. A Theory of Optimal Life Insurance: Development and Test, Journal of Finance, Volume 27, pp. 587-600.

xx. Goldsmith, Art, 1983. Household Life Cycle Protection: Human Capital versus Life Insurance. Journal of Risk and Insurance, Volume 50, pp. 33-44. 
xxi. Greene, M. R., 1954. Life Insurance Buying in Inflation. Journal of the American Association of University Teachers of Insurance, Volume 21, pp. 99-113.

xxii. Hakansson, N. H., 1969. Optimal Investment and Consumption Strategies Under Risk, and Uncertain Lifetime and Insurance. International Economic Review, Volume 10, pp. 443-466.

xxiii. Hammond, J. D., Houston, David B. and Melander, Eugene R., 1967. Determinants of Household Life Insurance Premium Expenditure: An Empirical Investigation. Journal of Risk and Insurance, Volume 34, pp. 397-408.

xxiv. Hau, A., 2000. Liquidity, Estate Liquidation, Charitable Motives, and Life Insurance Demand by Retired Singles. Journal of Risk and Insurance, Volume 67, pp. 123-141.

xxv. Headen, R. S., and Lee, J. F., 1974. Life Insurance Demand and Household Portfolio Behavior. Journal of Risk and Insurance, Volume 41, pp. 685-698.

xxvi. Heir, Anderson, Tatham \& Black, 2006.Multivariate Data Analysis. New Delhi: Pearson Education.

xxvii. Hinkin, T. R., 1995. A review of scale development practices in the study of organizations. Journal of Management, 21(5), pp. 967-988.

xxviii. Hofflander, A. E., and Duvall, R. M., 1967. Inflation and the Sales of Life Insurance, Journal of Risk and Insurance, Volume 34, pp. 355-361.

xxix. Hwang T. And Greenford B., 2005. A Cross-Section Analysis of the Determinants of Life Insurance Consumption in Mainland China, Hong Kong and Taiwan. Risk Management And Insurance Review, 8 (1), pp. 103-125.

xxx. Lewis, Frank D.,1989. Dependents and the Demand for Life Insurance, American Economic Review, Volume 79, pp. 452-466.

xxxi. Lim C.C. and Haberman S., 2004.Modelling Life Insurance Demand from a Macroeconomic Perspective: The Malaysian Case. Rome: Paper Presented at The $8^{\text {th }}$ International Congress of Insurance.

xxxii. Mantis, G., and Farmer, R., 1968. Demand for Life Insurance. Journal of Risk and Insurance, Volume 35, pp. 247-256.

xxxiii. Miller, M. A., 1985. Age-Related Reductions in Workers' Life Insurance. Monthly Labor Review Volume 9, pp. 29-34.

xxxiv. Neumann, S., 1969. Inflation and Saving Through Life Insurance. Journal of Risk and Insurance, Volume 36, pp. 567-582.

xxxv. Outtreville J.F., 1996. Life Insurance Markets in Developing Countries. The Journal of Risk and Insurance, 63 (2), pp. 263-278.

xxxvi. Pissarides, C. A.,1980. The Wealth-Age Relation with Life Insurance. Economica, Volume 47, pp. 451-457.

xxxvii. Showers, V. E., and Shotick J. A., 1994. The Effects of Household Characteristics on Demand for Insurance: A Tobit Analysis. Journal of Risk and Insurance, Volume 61, pp. 492- 502.

xxxviii. Truett, D. B., and Truett, L. J., 1990. The Demand for Life Insurance in Mexico and the United States: A Comparative Study. Journal of Risk and Insurance, Volume 57, pp. 321-328.

xxxix. Ward, D. And Zubruegg, R., 2002. Law, Politics and Life Insurance Consumption in Asia. The Geneva Papers On Risk And Insurance: Issues And Practice, Volume 27, pp. 395-412.

xl. Williams, A., 1986. Higher Interest Rates, Longer Lifetimes, and the Demand for Life Annuities. Journal of Risk and Insurance, Volume 53, pp. 164-171.

xli. Yaari, Menahem E., 1965. Uncertain Lifetime, Life Insurance, and the Theory of the Consumer. Review of Economic Studies, Volume 32, pp. 137-150. 
xlii. Zelizer, Vivan R., 1979.Morals and Markets: The Development of Life Insurance in the United States. New York: Columbia University Press.

xliii. Zietz, Emily Norman, 2003.An Examination of the Demand for Life Insurance. Risk Management and Insurance Review, 6 (2), pp. 159-191. 